\title{
PCM1 wt Allele
}

National Cancer Institute

\section{Source}

National Cancer Institute. PCM1 wt Allele. NCI Thesaurus. Code C97901.

Human PCM1 wild-type allele is located within 8p22-p21.3 and is approximately $107 \mathrm{~kb}$ in length. This allele, which encodes pericentriolar material 1 protein, plays a role in the regulation of centrosome formation. A chromosomal translocation $t(8 ; 10)(p 21.3 ; q 11.2)$ of this gene and the RET gene is associated with papillary thyroid carcinoma. A second translocation $\mathrm{t}(8 ; 9)(\mathrm{p} 22 ; \mathrm{p} 24)$ of this gene and the JAK2 gene is found in a variety of hematological malignancies including atypical chronic myeloid leukemia and T-cell lymphoma. 